\title{
Hubungan Tingkat Pendidikan Dengan Angka Kejadian Kondiloma Akuminata
}

\author{
Eka Silvia $^{1}$, Tusy Triwahyuni ${ }^{2}$, M.Syafei Hamzah ${ }^{3}$, Rian Hazni ${ }^{4 *}$
}

${ }^{1)}$ Departemen Ilmu Kesehatan Fakultas Kedokteran, Universitas Malahayati, bundaekas18@gmail.com

${ }^{2}$ Departemen Parasitologi Fakultas Kedokteran, Universitas Malahayati

${ }^{3}$ Departemen Dermatologi \& Venereologi, Fakultas Kedokteran, Universitas Malahayati, mazcosyaf@yahoo.com

${ }^{4)}$ Program Studi Kedokteran, Fakultas Kedokteran, Universitas Malahayati, rianhazni.rh@gmail.com

\begin{abstract}
ABSTRAK
Kondilomata Akuminata atau yang sering disebut sebagai atau kutil kelamin yang disebabkan oleh human papiloma virus (HPV) tipe tertentu terutama tipe 6 dan 11. Tingkat pendidikan merupakan salah satu faktor sosial yang turut berperan dalam menunjang seseorang menerima pengetahuan dan informasi mengenai penyakit kondiloma akuminata, di mana semakin tinggi tingkat pendidikan seseorang biasanya mempunyai pengertian yang lebih besar terhadap masalah-masalah kesehatan dan pencegahannya, begitu pula sebaliknya semakin rendah tingkat pendidikan seseorang menyebabkan semakin terbatasnya pengetahuan tentang bahaya perilaku tidak sehat, sehingga mereka tidak termotivasi untuk mengadopsi gaya hidup sehat. Penelitian ini bertujuan untuk mengetahui hubungan antara tingkat pendidikan dengan angka kejadian kondiloma akuminata di Poliklinik Kulit dan Kelamin RSUD. Dr. H. Abdul Moeloek Provinsi Lampung periode 2018-2020. Jenis penelitian ini adalah analitik observasional, dengan rancangan penelitian cross-sectional, dan dengan pengumpulan data sekunder kondiloma akuminata dan tingkat pendidikan. Klasifikasi tingkat pendidikan disesuaikan menurut Undang-Undang Republik Indonesia Nomor 20 Tahun 2003 Tentang Sistem Pendidikan Nasional. Teknik pengambilan sample berupa total sampling. Pengumpulan data dilakukan dengan cara melihat data rekam medik serta dianalisis menggunakan uji Spearman. Hasil Penelitian didapatkan dari 102 orang sesuai sampel yang didapat. Pada penderita kondiloma akuminata dengan frekuensi tingkat pendidikan terbanyak yaitu pada pendidikan rendah sebanyak 49,3\%. Hasil uji statistik Sperman diperoleh $p=0,009(p<0,05)$ dengan nilai $r=0,256$. Kesimpulan hasil akhir menunjukkan terdapat hubungan yang signifikan antara tingkat pendidikan dengan kondiloma akuminata, dan semakin tinggi tingkat pendidikan yang rendah maka semakin tinggi angka kejadian kondiloma akuminata.
\end{abstract}

Kata kunci : Kondiloma akuminata, Tingkat Pendidikan

\begin{abstract}
Condyloma acuminata or what is often referred to as or genital warts caused by certain types of human papilloma virus (HPV) especially types 6 and 11. The level of education is one of the social factors that play a role in supporting a person to receive knowledge and information about condyloma acuminata disease, where the higher the level of education of a person usually has a greater understanding of health problems and their prevention, as well as the lower the level of one's education causes the more limited knowledge about the dangers of unhealthy behavior, so that they are not motivated to set a healthy lifestyle The purpose of this research is to determine the correlation between education level and the incidence of condyloma acuminata in dermatovenerology polyclinic of regional general hospital DR. H. Abdul Moeloek Lampung Province 2020. type of this research is analytic observational, with a cross-sectional study design, and with secondary data collection of condyloma acuminata and education level. The education level classification is adjusted according to the Law of the Republic of Indonesia Number 20 of 2003 concerning the National Education System. The technical of collecting the sample is total sampling. Data was collected by looking at medical record data and analyzed using the Spearman test. Results Obtained from 102 people according to the sample obtained. In patients with condyloma acuminata, the highest education level was 49.3\%. The results of the Sperman statistical test obtain $p=0.009(p<0.05)$ with a value of $r=$ 0.256. Conclusion The final results showed that there was a significant relationship between the level of education and condyloma acuminata, the higher the level of education is lower, the higher the incidence of condyloma acuminata.
\end{abstract}

Keywords : Condyloma acuminata, Education Level

* Korespondensi Author : Rian Hazni, Fakultas Kedokteran Universitas Malahayati, rianhazni.rh@gmail.

\section{PENDAHULUAN}

Kondilomata akuminata adalah tumor yang terdapat pada genitalia yang dengan pertumbuhannya bersifat jinak, konsistensinya lunak seperti jengger ayam dan tidak di sertai dengan rasa nyeri. ${ }^{1}$

Kondiloma akuminata (KA) disebut juga kutil anogenital, kutil kelamin, atau kutil 
venereal adalah infeksi yang disebabkan Human Papilloma Virus (HPV) di daerah perineum, genitalia merupakan penyakit menular seksual paling sering di dunia. Kondiloma akuminata dapat disebabkan oleh berbagai subtipe HPV, terutama HPV 6 dan 11, sedangkan HPV 16 dan 18 merupakan penyebab kanker invasive da traktus genitalis dan anus. ${ }^{2}$

Terdapat beberapa faktor yang mempengaruhi banyaknya terjadinya kondiloma akuminata adalah disebabkan karena aktivitas seksual, mempunyai pasangan lebih dari 1 orang (multiple), merokok, kehamilan, riwayat IMS dan penurunan daya tahan tubuh juga akan mempermudah terjadinya infeksi kondiloma akuminata. Peningkatan insiden kondiloma akuminata dipengaruhi oleh faktor risiko yang mempermudah transmisi kondiloma akuminata yaitu, umur, jenis kelamin, tingkat pendidikan, status perkawinan. Salah satu faktornya adalah pendidikan dimana tingkat pendidikan berpengaruh terhadap pengetahuan, sikap dan perilaku seksual seseorang. ${ }^{3}$

Pendidikan merupakan salah satu faktor sosial yang turut berperan dalam menunjang seseorang menerima pengetahuan dan informasi mengenai pengetahuan tentang penyakit kondiloma akuminata, dimana semakin tinggi tingkat pendidikan seseorang biasanya mempunyai pengertian yang lebih besar terhadap masalah-masalah kesehatan dan pencegahannya, begitupula sebaliknya semakin rendah tingkat pendidikan seseorang menyebabkan semakin terbatasnya pengetahuan tentang bahaya perilaku tidak sehat, sehingga mereka tidak termotivasi untuk mengadopsi gaya hidup sehat. ${ }^{4}$

Berdasarkan hasil penelitian yang dilakukan di Bandar Lampung (2017) distribusi frekuensi dari 81 pasien kondiloma akuminata yang menjadi subjek penelitian. Responden dengan riwayat pendidikan tinggi sebanyak 15 orang $(18,5 \%)$ dan riwayat pendidikan rendah sebanyak 66 orang $(81,5 \%)$. Pendidikan rendah berpengaruh terhadap pengetahuan, sikap dan perilaku seksual seseorang dan sangat berasosiasi kuat dengan kejadian kondiloma akuminata sehingga orang dengan tingkat pendidikan rendah risiko terinfeksi KA meningkat secara signifikan. ${ }^{3}$ Sedangkan hasil penelitian yang dilakukan di hotspot X Pekan baru (2018) di ditemukan bahwa dari 49 sampel, mayoritas dari mereka memiliki tingkat pendidikan SMP sebesar 49\%, dan minoritas memiliki tingkat pendidikan Perguruan Tinggi sebesar $2 \%$, sedangkan untuk pendidikan SD dan SMA masing-masing 22,4\% dan26,5\%. ${ }^{5}$

Oleh sebab itu, penelitian ini bertujuan untuk membuktikan ada tidaknya hubungan antara tingkat pendidikan dengan angka kejadian kondiloma akuminata di Poliklinik Kulit dan Kelamin RSUD. Dr. H. Abdul Moeloek Provinsi Lampung periode 2018-2020.

\section{METODOLOGI}

Jenis penelitian ini adalah analitik observasional, dengan rancangan penelitian cross-sectional. Populasi dalam penelitian ini adalah pasien kondiloma akuminata dan sifilis yang diambil dari rekam medik periode Januari 2018-Desember 2020 di Poliklinik Kulit dan Kelamin RSUD Dr. H. Abdul Moeloek Provinsi Lampung yang digunakan pada penelitian ini adalah 102 orang yang terdiri dari 71 pasien kondiloma akuminata dan 31 pasien sifilis. Pengambilan data penyakit sifilis dilakukan untuk digunakan sebagai pembanding dari penyakit kondiloma akuminata. Cara pengambilan sampel melalui Total sampling. Yang termasuk kriteria inklusi pada penelitian ini yaitu :

a. Seluruh pasien yang terdiagnosa kondiloma akuminata di poli klinik kulit dan kelamin RSUD Dr. H. Abdul Moeloek Lampung Pada Periode 2018-2020.

b. Seluruh pasien yang terdiagnosa sifilis di poli klinik kulit dan kelamin RSUD Dr. H. Abdul Moeloek Lampung Pada Periode 2018-2020.

Adapun kriteria ekslusi dari penelitian ini yaitu :

a. Pasien kondiloma akuminata dengan data pendidikan yang tidak lengkap.

b. Pasien sifilis dengan data pendidikan yang tidak lengkap.

Variabel independen dalam penelitian adalah tingkat pendidikan. Sedangkan variabel dependen, yaitu kondiloma akuminata. Analisis data bivariat digunakan dalam penelitian ini adalah dengan spearman, yaitu uji yang digunakan untuk hubungan antara tingkat pendidikan dengan angka kejadian kondiloma akuminata di Poliklinik Kulit dan Kelamin RSUD Dr. H. Abdul Moeloek Provinsi lampung Periode 2018-2020.

\section{HASIL DAN PEMBAHASAN}

a. Uji Normalitas 
Hasil uji normalitas dengan metode Kolmogorov-Smirnov, didapatkan nilai signifikasi sebesar 0,000 untuk KA dan 0,000 untuk tingkat pendidikan, oleh karena keduanya memiliki nilai signifikan $<0,05$ maka data kondiloma akuminata dan tingkat pendidikan tidak terdistribusi normal, sehingga uji korelasi yang dipakai dalam penelitian ini adalah uji Spearman.

b. Analisis Univariat

1. Karakteristik distribusi frekuensi angka kejadian penyakit kondiloma akuminata dan sifilis periode 2018-2020 di Poliklinik Kulit dan Kelamin RSUD Dr. H. Abdul Moeloek Provinsi Lampung.

\section{Gambar 1. Distribusi frekuensi angka} kejadian penyakit

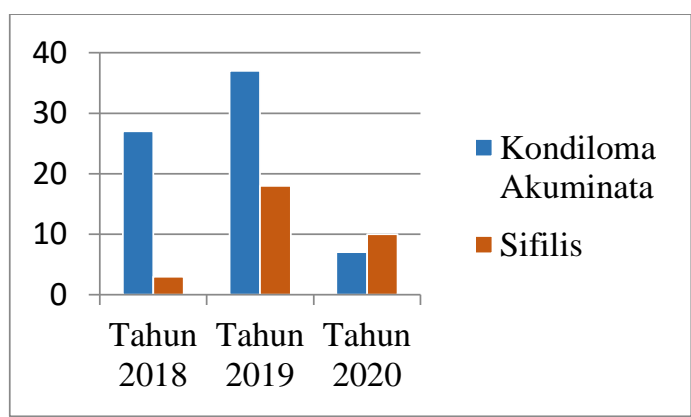

Berdasarkan gambar 1. Diatas menunjukan bahwa distribusi frekuensi angka kejadian penyakit kondiloma akuminata pada tahun 2018 sebanyak 27 pasien, pada tahun 2019 terjadi peningkatan jumlah pasien sebanyak 37 pasien, dan mengalami penurunan pada tahun 2020 sebanyak 7 pasien. Sedangkan untuk penyakit sifilis pada tahun 2018 sebanyak 3 pasien, kemudian terjadi peningkatan pada tahun 2019 sebanyak 18 pasien, dan terjadi penurunan pada tahun 2020 sebanyak 10 pasien. Pada tahun 2020 dari kedua penyakit terjadi penurunan yang sangat drastis dikarenakan terjadinya pandemi covid-19, dan anjuran pemerintah untuk stay at home.

2. Karakteristik distribusi frekuensi responden Berdasarkan Angka Kejadian kondiloma akuminata dan sifilis di Poliklinik Kulit dan Kelamin RSUD Dr. H. Abdul Moeloek Provinsi Lampung

Tabel 1. Distribusi Frekuensi Responden Berdasarkan Angka Kejadian Periode 2018-2020

\begin{tabular}{ccc}
\hline $\begin{array}{c}\text { Angka } \\
\text { Kejadian }\end{array}$ & Frekuensi & Persentase \\
\hline $\begin{array}{c}\text { Kondiloma } \\
\text { Akuminata }\end{array}$ & 71 & $69,6 \%$ \\
\hline Sifilis & 31 & $30,4 \%$ \\
\hline Total & $\mathbf{1 0 2}$ & $\mathbf{1 0 0 \%}$ \\
\hline
\end{tabular}

Berdasarkan tabel 1. diatas menunjukkan bahwa distribusi frekuensi kejadian Kondiloma akuminata di Poliklinik Kulit dan Kelamin RSUD Dr. H. Abdul Moeloek Provinsi Lampung periode 2018-2020 sebanyak 71 orang $(69.6 \%)$ mengalami KA dan 31 orang $(30.4 \%)$ mengalami sifils.

3. Karakteristik Berdasarkan Tingkat Pendidikan

Tabel 2. Distribusi Frekuensi Tingkat Pendidikan Responden Kondiloma Akuminata periode 2018-2020

\section{Kondiloma Akuminata}

\begin{tabular}{ccc}
\hline $\begin{array}{c}\text { Tingkat } \\
\text { Pendidikan }\end{array}$ & Frekuensi & Persentase \\
\hline Rendah & 35 & $49.30 \%$ \\
\hline Sedang & 22 & $31 \%$ \\
\hline Tinggi & 14 & $19,7 \%$ \\
\hline Total & $\mathbf{7 1}$ & $\mathbf{1 0 0 \%}$ \\
\hline
\end{tabular}

Berdasarkan tabel 2. diatas menunjukan bahwa distribusi frekuensi penyakit kondiloma akuminata terbanyak berdasarkan tingkat pendidikan adalah tingkat pendidikan rendah sebanyak 35 orang $(49.3 \%)$, tingkat pendidikan sedang sebanyak 22 (31\%), dan tingkat pendidikan tinggi sebanyak 14 orang $(19.7 \%)$.

c. Analisis Bivariat

Tabel 3. Hasil Analisis Uji Spearman

\begin{tabular}{cccc}
\hline Variabel & $\mathbf{n}$ & $\begin{array}{c}\mathbf{p}- \\
\text { value }\end{array}$ & $\mathbf{r}$ \\
\cline { 1 - 1 } Kondiloma Akuminata & 102 & & \\
\cline { 1 - 2 } Tingkat Pendidikan & 102 & 0.009 & +0.256
\end{tabular}

Pada uji analisis bivariat peneliti menguji antara hubungan tingkat pendidikan dengan angka kejadian kondiloma akuminata di Poliklinik Kulit dan Kelamin RSUD Dr. H. 
Abdul Moeloek Provinsi Lampung Periode 2018-2020. Berdasarkan hasil uji statistik Spearman pada tingkat pendidikan dengan kondiloma akuminata diperoleh nilai p-valuel signifikansi $=0,009(\mathrm{P}<0,05)$, artinya terdapat "hubungan bermakna antara Tingkat Pendidikan dengan Kondiloma Akuminata ". Nilai korelasi r $=+0,256$ artinya kekuatan korelasi penelitian ini memiliki keterkaitan dan mempunyai arah kolerasi positif yang dapat disimpulkan bahwa bahwa semakin tinggi tingkat pendidikan yang rendah maka semakin tinggi pula angka kejadian kondiloma akuminata. ${ }^{6}$

HPV adalah virus DNA beruntai ganda yang biasa menyebar langsung dari kulit ke kulit dengan orang yang terinfeksi, biasanya saat berhubungan seks. Umur, gaya hidup, dan aktivitas seksual menjadi faktor utama yang dapat menyebabkan seseorang rentan terjangkit HPV dan mengalami Kondiloma akuminata. ${ }^{7}$

Kondiloma akuminata atau genital warts atau juga yang lebih dikenal oleh masyarakat awam dengan istilah penyakit kutil kelamin ataupun penyakit jengger ayam digolongkan dalam penyakit menular seksual yang disebabkan oleh Human Papiloma Virus (HPV) . Saat ini telah dikenal lebih dari 120 subtipe HPV, namun yang bertanggung jawab terhadap terjadinya KA yang tersering adalah subtipe 6 dan 11. Dan subtipe 16 dan 18 diduga mempunyai kecenderungan ongkogenik menjadi penyebab keganasan pada leher Rahim. ${ }^{8}$

Tingkat pendidikan merupakan salah satu faktor sosial yang turut berperan dalam menunjang seseorang menerima pengetahuan dan informasi, dimana semakin tinggi tingkat pendidikan seseorang biasanya mempunyai pengertian yang lebih besar terhadap masalahmasalah kesehatan dan pencegahannya, begitupula sebaliknya semakin rendah tingkat pendidikan seseorang menyebabkan semakin terbatasnya pengetahuan tentang bahaya perilaku tidak sehat, sehingga mereka tidak termotivasi untuk mengadopsi gaya hidup sehat. ${ }^{4}$ Tingkat pendidikan berpengaruh terhadap pengetahuan, sikap dan perilaku seksual seseorang sehingga sangat berasosiasi kuat dengan kejadian kondiloma akuminata. Makin rendah tingkat pendidikan makin besar risiko menderita kondiloma akuminata. Tingkat pendidikan yang rendah merupakan faktor risiko untuk menderita kondiloma akuminata. ${ }^{(9)}$

Berdasarkan hasil penelitian ditemukan 71 pasien KA di Poliklinik Kulit dan Kelamin RSUD Dr. H. Abdul Moeloek dengan rata-rata responden paling banyak memiliki tingkat pendidikan rendah sebanyak 35 orang (49.3\%), kemudian untuk tingkat pendidikan sedang sebanyak 22 orang (31\%) dan yang terakhir untuk tingkat pendidikan tinggi didapatkan data sebanyak 14 orang (19.7\%). Populasi dan sampel pada penelitian ini bertambah dikarenakan data presurvey hanya diambil sampai dengan bulan Oktober 2020, sedangkan pada penelitian ini data diambil hingga bulan Desember 2020. Data fluktuatif pasien KA tahun 2020 merupakan salah satu dampak dari pandemi covid-19 yang mengakibatkan penurunan jumlah pasien. Dan hasil akhir menunjukan bahwa terdapat hubungan yang siginfikan antara tingkat pendidikan dengan angka kejadian kondiloma akuminata, p-valuel signikikansi $0,009<0.05$.

Penelitian ini sejalan dengan hasil penelitian sebelumnya yang dilakukan Puteri Maharani, dkk, pada April 2017 sampai dengan Juli 2018 di hotspot X Pekanbaru ditemukan bahwa dari 49 sampel, mayoritas dari mereka memiliki tingkat pendidikan SMP sebesar 49\%, dan minoritas memiliki tingkat pendidikan Perguruan Tinggi sebesar 2\%, sedangkan untuk pendidikan SD dan SMA masing-masing 22,4\% dan 26,5\%.(5) Tingkat pendidikan merupakan salah satu faktor yang memengaruhi kualitas hidup. Semakin tinggi pendidikan yang dimiliki maka semakin bagus pula kualitas hidupnya. ${ }^{10}$

Tingkat pendidikan juga merupakan salah satu faktor yang dapat mempengaruhi kualitas hidup, hasil penelitian menunjukkan bahwa tingginya signifikansi perbandingan dari pasien yang berpendidikan tinggi meningkat dalam keterbatasan fungsional yang berkaitan dengan masalah emosional dari waktu ke waktu dibandingkan dengan pasien yang berpendidikan rendah serta menemukan kualitas hidup yang lebih baik bagi pasien berpendidikan tinggi dalam domain fisik dan fungsional, khususnya dalam fungsi fisik, energi /kelelahan, sosial, dan keterbatasan dalam peran berfungsi terkait dengan masalah emosional. ${ }^{11}$

Penelitian ini juga sejalan dengan hasil penelitian sebelumnya yang dilakukan Merry Putri, dkk, di Poliklinik Kulit dan Kelamin RSUD Dr. H. Abdul Moeloek tahun 2016, bahwa terdapat 81 kasus pasien kondiloma akuminata yang menjadi subjek penelitian. Responden dengan riwayat pendidikan tinggi sebanyak 15 orang $(18,5 \%)$ dan riwayat pendidikan rendah sebanyak 66 orang $(81,5 \%)$. Rata-rata pasien kondiloma akuminata memiliki 
riwayat pendidikan rendah yaitu $<9$ tahun. $^{3}$ Pendidikan rendah berpengaruh terhadap pengetahuan, sikap dan perilaku seksual seseorang dan sangat berasosiasi kuat dengan kejadian kondiloma akuminata sehingga orang dengan tingkat pendidikan rendah risiko terinfeksi KA meningkat secara signifikan. ${ }^{3}$

Namun hasil penelitian ini berbeda dengan yang dilakukan oleh Ida Bagus dan Agung, dengan sampel 58 pasien penderita kondiloma akuminata dengan HIV di Poliklinik RSUP Sanglah pada periode Januari 2011 sampai dengan Desember 2015, didapatkan yaitu sebanyak 5 orang $(8,6 \%)$ penderita KA mempunyai tingkat pendidikan rendah, 31 orang $(53,5 \%)$ mempunyai tingkat pendidikan menengah, dan 22 orang $(37,9 \%)$ mempunyai tingkat pendidikan tinggi. ${ }^{12}$ Dapat disimpulkan bahwa, prevalensi KA terbanyak pada penelitian ini adalah tingkat pendidikan menengah. Secara fisiologis, pada tingkat pendidikan ini kebanyakan adalah remaja yang merupakan perubahan masa transisi dari anak-anak menuju dewasa. Pada periode ini berbagai perubahan terjadi baik perubahan hormonal, fisik, psikologis maupun sosial. Perubahan ini terjadi dengan sangat cepat dan terkadang tanpa kita sadari. Perubahan fisik yang menonjol adalah perkembangan tanda-tanda seks sekunder, terjadinya pacu tumbuh, serta perubahan perilaku dan hubungan sosial dengan lingkungannya. Perubahan-perubahan tersebut dapat mengakibatkan kelainan maupun penyakit tertentu bila tidak diperhatikan dengan seksama. $^{13}$ Maturasi seksual terjadi melalui tahapan-tahapan yang teratur yang akhirnya mengantarkan anak siap dengan fungsi fertilitasnya, laki-laki dewasa dengan spermatogenesis, sedangkan anak perempuan dengan ovulasi. Di samping itu, juga terjadi perubahan psikososial anak baik dalam tingkah laku, hubungan dengan lingkungan serta ketertarikan dengan lawan jenis. Perubahanperubahan tersebut juga dapat menyebabkan hubungan antara orangtua dengan remaja menjadi sulit apabila orangtua tidak memahami proses yang terjadi. ${ }^{13}$

Berdasarkan hasil observasi ditemukan sekitar 69.6\% kejadian KA di Poliklinik Kulit dan Kelamin RSUD Dr. H. Abdul Moeloek dengan data tingkat pendidikan rendah sebanyak 35 orang $(49.3 \%)$, kemudian untuk tingkat pendidikan sedang sebanyak 22 orang (31\%), dan yang terakhir utntuk tingkat pendidikan tinggi didapatkan data sebanyak 14 orang
(19.7\%). Dan hasil akhir menunjukan bahwa terdapat hubungan yang siginfikan dengan korelasi cukup kuat yang positif. Semakin tinggi tingkat pendidikan yang rendah, maka semakin tinggi angka kejadian kondiloma akuminata. Hal ini menunjukan bahwa diperlukan pemberian informasi kepada pasien kondiloma akuminata mengenai faktor-faktor yang mempengaruhinya.

\section{SIMPULAN DAN SARAN}

Berdasarkan hasil penelitian yang dilakukan pada pasien kondiloma akuminata di Poliklinik Kulit dan Kelamin RSUD Dr. H. Abdul Moeloek Provinsi Lampung Periode 2018-2020, maka didapat kesimpulan bahwa sebagian besar pasien penderita kondiloma akuminata adalah berpendidikan rendah dan diketahui terdapat hubungan yang signifikan antara tingkat pendidikan dengan angka kejadian kondiloma akuminata di Poliklinik Kulit dan Kelamin RSUD Dr.H. Abdul Moeloek Provinsi Lampung periode 2018-2020 dengan hasil $\mathrm{p}=0,009(\mathrm{p}<0,05)$.

Saran untuk peneliti selanjutnya perlu dilakukan penelitian lebih lanjut dengan rancangan selain cross sectional dan jumlah sampel yang lebih banyak. Diperlukan juga penelitian dan pembahasan yang lebih detail mengenai faktor-faktor lain yang memicu terjadinya penyakit kondiloma akuminata. Saran untuk institusi pendidikan Hasil penelitian ini di harapkan dapat memberikan informasi yang telah ada sebelumnya serta menunjang kegiatan penelitian selanjutnya di Fakultas Kedokteran Universitas Malahayati. Saran untuk masyarakat diharapkan untuk dapat menjaga diri dalam berhubungan seksual tidak bergonta ganti pasangan guna mencegah kondiloma akuminata, dan penyakit IMS lainnya,serta menerapkan pola hidup sehat.

\section{UCAPAN TERIMA KASIH}

Saya ucapakan terimakasih banyak kepada para dosen pembimbing serta penguji yang telah meluangkan waktunya dan membimbing saya dalam penulisan skripsi ini, tak lupa saya ucapkan terimakasih kepada orang tua dan saudara, serta teman teman yang selalu memberikan doa dan dukungan.

\section{REFERENSI}

1. R Clevere S, Made Ari GA. Penyakit Kulit dan Kelamin. Yogyakarta: Nuha Medika; 2013. 140-141 p.

2. Dhamayanti ME, Rahayu T, Wirawan 
EP,Terapi Kondiloma Akuminata dengan Kombinasi Trichloroacetic Acid (TCA) 80\%+ Krioterapi. Cermin Dunia [Internet]. 2019;46(6):443-7. Available from:http://103.13.36.125/index.php/CDK/ article/viewFile/469/257

3. Hernisa MP. Analisis faktor-faktor yang berhubungan dengan kondiluma akuminata di Poliklinik Kulit dan Kelamin RSUD Dr. H. Abdul Moeloek Bandarlampung tahun 2016. J Ilmu Kedokt dan Kesehat. 2017;4(1):8-11.

4. Pampel FC, Krueger PM, Denney JT. Socioeconomic disparities in health behaviors. Annu Rev Sociol. 2010;36:34970.

5. Maharani P, Amtarina R, Widiawaty A. Hubungan Kejadian Kondiloma Akuminata Terhadap Kualitas Hidup Pekerja Seks Komersial di Hotspot Pekanbaru. J Ilmu Kedokt. 2019;12(2):82.

6. Dahlan S. Statistik Untuk Kedokteran dan Kesehatan. Jakarta: Salemba Medika; 2013. $77 \mathrm{p}$.

7. Mahony CO, Gomberg $\mathrm{M}$, Skerlev $\mathrm{M}$, Alraddadi A, Heras-alonso ME De, Majewski S, et al. Position statement for the diagnosis and management of anogenital warts. 2019;1006-19.
8. Ratnasari DT, Kulit B, Kedokteran F, Wijaya U, Surabaya K. Kondiloma Akuminata Condyloma Accuminatum. 1978;2071(2):18-21.

9. Patel H, Wagner M, Singhal P, Kothari S. Systematic review of the incidence and prevalence of genital warts. BMC Infect Dis [Internet]. 2013;13(1):1. Available from: BMC Infectious Diseases

10. Wahl AK, Rustøen T, Hanestad BR, Lerdal A, Moum T. Quality of life in the general Norwegian population, measured by the Quality of Life Scale ( QOLS-N ). 2004;1001-9.

11. Barbareschi G, Sanderman R, Leegte IL, Van Veldhuisen DJ, Jaarsma T. Educational level and the quality of life of heart failure patients: A longitudinal study. J Card Fail [Internet]. 2011;17(1):47-53. Available from: http://dx.doi.org/10.1016/j.cardfail.2010.08. 005

12. Bagus I, Jayadharma G, Agung A, Putra G. Gambaran karakteristik pasien kondiloma akuminata dengan infeksi HIV / AIDS di RSUP Sanglah , Denpasar, Indonesia tahun 2011-2015. 2020;11(3):1308-12.

13. Batubara JRL. Adolescent Development. 2010;12(1):21-9. 